\title{
SEX-RELATED EFFECTS ON LATENT TOXOPLASMOSIS COURSE INDUCED IN MICE
}

\author{
$\mathscr{B}_{y}$ \\ Mamdouh Hegazya , Manar Azaba, Nora El-Tantawya, \\ Manar El-Mehankara, Azza Abdel-Aziz ${ }^{\mathbf{b}}$ \\ From \\ a Department of Parasitology, Faculty of Medicine, Mansoura University, 35516, Egypt \\ ${ }^{b}$ Department of Pathology, Faculty of Medicine, Mansoura University, 35516, Egypt
}

\begin{abstract}
Background: Sex-associated hormones influence the severity of Toxoplasma gondii infection especially during pregnancy and if immmunosuppression takes place.

Aim of the study: So, the aim of our work is to study sex-related effects on the course of chronic toxoplasmosis in mice.

Methods: Twenty male and $20 \mathrm{fe}$ male mice were artificially infected with cystogenic type II ME49 Toxoplasma strain. The morbidity was assessed in both sexes in acute stage by observing clinical signs of toxoplasmosis besides examination of peritoneal aspirate for tachyzoites. In chronic stage, morbidity was as-
\end{abstract}

sessed by estimation of brain cyst burden, histopathological examination and monitoring serum antiToxoplasma IL- 12 using ELISA.

Results: There was no significant difference between males and females regarding clinical signs in acute stage. In chronic stage, females have more brain cyst count and more pathological lesions than males. Moreover, the results obtained by measurement of antiToxoplasma IL-12 showed high levels in male than female group.

Conclusion: Our results demonstrated that male mice are less susceptible to infection while, female ones are more susceptible and showing exaggerated inflammatory

MANSOURA MEDICAL JOURNAL 
reaction and more cysts count in brain.

Keywords: Toxoplasmosis, mice, sex, IL-12, histopathology

\section{INTRODUCTION}

Toxoplasma gondii is a ubiquitous obligate intracellular parasite that can infect various organs and tissues of over 350 species of haemothermic vertebrates including man, livestock and marine mammals, being from this point of view, probably the most polyxenous protozoan [1, 2]. Approximately one third of the human population are infected with Toxoplasma gondii [3], thus this parasite ranks third among the most widespread parasitic diseases throughout the world [4]. Toxoplasma gondii has emerged as a major opportunistic pathogen of immunocompromised individuals [5].

The parasite has a heteroxenous life cycle with haemothermic vertebrates as intermediate hosts and felines as definitive hosts [6]. Risk factor analysis indicates that $30-63 \%$ of human post natal infections can be attributed to the consumption of raw or undercooked meat containing cysts [7]. Food and water contaminated with the oocysts passed in the cat faeces is another important method of postnatal acquired transmission [8]. Congenital transmission can take place if a woman gets infected for the first time during her pregnancy [9].

Irrespective of which of the life cycle stages initiates the infection, the parasite undergoes an initial period of rapid multiplication as a tachyzoite stage in almost all tissues of the host [10]. Around 10-15 days postinfection and as a result of a developing immune response preventing further multiplication, parasites transform into bradyzoites which form tissue cysts predominantly in the central nervous system and skeletal muscles which remain viable for the life of the host [11].

The immune response to Toxoplasma gondii is typically cellular and is orchestrated by macrophages, dendritic cells and natural killer cells [12]. However, T-cells particularly CD8+ and CD4+ T-cells work together in synergy to produce IFN- $\gamma$ an important cytokine involved in the control of Toxoplasma replication [13]. 
Mamdouh Hegazya et al ....

The population of Toxoplasma of hormonal influence on immune regondii is maintained in three lineages designed types I-III. The type I ( $\mathrm{RH}$ strain) is uniformly lethal to BALB/c mice causing death in 4-6 days. Type II (ME 49 strain), and type III (strain M7741) are less virulent and can establish chronic infections. Type II strain is the one most commonly isolated from human clinical cases [14].

The literature is full of observations that both the incidence and severity of natural parasitic infections are different between males and females in many species including man. In humans, male-biased infections have been reported in malaria [15] and in leishmaniasis [16]. Although sexual dicotomy was attributed to epidemiological and genderassociated behavioral factors as males are more likely to engage in behaviors as aggression and dispersal which increases the likelihood of contact with parasites [17], yet, under controlled laboratory conditions, a clear dicotomy in the susceptibility of males and females was proved which clearly clarifies the role of hormone-influenced immunological mechanisms. The overall paradigm sponse stipulates that estrogen enhances immune response, while testosterone and progesterone decrease it [18]. Female resistance to infections caused by parasites is positively associated with estrogen concentration [19]. Estrogen has been showen to modify the activity of macrophages to phagocytose and influence IFN- $\gamma$ production [20]. Castration of male mice reduces, whereas exogenous administration of testosterone increases their mortality following infection with Plasmodium chabaudi, Plasmodium berghei and Leishmania major [21] .

In toxoplasmosis human studies on sex differences are scarce because most of infected healthy adults are asymptomatic. However, among immunocompromised individuals, Toxoplasma gondii-induced encephalitis is more prevalent among women than men [22]. In a murine model of toxoplasmosis, Henry and Beverly (1976) [23], were the first to demonstrate differences in the immune and inflammatory responses of male and female mice recording severe brain inflammatory lesions in females than males. Ovariectomy of

MANSOURA MEDICAL JOURNAL 
female mice reduces, whereas administration of estradiol exacerbates the development of tissue cysts [24]. Male mice have been proved to be less susceptible to Toxoplasma infection than females [25]. In other studies male mice were found to produce higher concentrations of TNF$\alpha$, IFN- $\gamma$ and IL12 than females [26].

Our aim was to study sex-related effects on the course of latent toxoplasmosis experimentally in mice, that may explain to how extent sex-and pregnancy-associated hormones can influence the severity of toxolplasmosis. Besides, clarifying the extent of toxoplasmosis lesions expected in either sex if immunocompromisation takes place.

\section{SUBJECTS, MATERIALS AND METHODS}

\section{1. Setting}

The use and care of animals in the study complied with the guidelines of Committee on Research Ethics, Mansoura Faculty of Medicine. The minimal number of animals required to obtain sufficiently valid results used. Care was taken to avoid infection of staff assisted in parasiteanimal passage.

Vol. 44, No. 1 \& 2 Jan. \& April, 2015
The study was conducted at the Parasitology and Pathology Department, Mansoura Faculty of Medicine and Nile center for experimental studies, Mansoura.

2. 2. Murine model of latent toxoplasmosis

Mice orally infected with the ME49 type II cystogenic Toxoplasma strain obtained from Parasitology Department, Alexandria Faculty of Medicine represented the experimental model for this study.

\section{2. 1. Parasite strain}

The cystogenic ME49 Toxoplasma type II strain was maintained by oral passage in Swiss Webster mice.

\section{2. 2. Mice}

Outbred male and female Swiss Webster mice 6-8 week old and weighing 25-30 gm were used. Mice were housed in a temperature controlled colony room $\left(21 \pm 2^{\circ} \mathrm{C}\right)$ in unisex groups of 5-7 in plastic cages with wood shaving beddings and maintained under a reversed 12hours light: dark cycles with food and water added at libetum. Mice were left under these conditions for one 
Mamdouh Hegazya et al ....

week before experimentation for acclimatization.

\section{2. 3. Preparation of cyst inocu-} lum

Brains of infected mice were harvested at least 8 weeks after oral infection and homogenized in $1 \mathrm{ml}$ buffered saline $\mathrm{pH} 7.2$ in Teflon homogenizer. The number of cysts in $10 \mu l$ of the homogenate was quantified in a haemocytometer under $X$ 400 magnification [27].

2. 3. Induction of infection for morbidity assessment

Twenty male and twenty female mice were inoculated intragastrically using 22-gauge blunt feeding needle with an amount of brain homogenate adjusted to contain 10 tissue cysts. Mice were left for an observation period of 6-10 weeks. A group of 6 mice ( 3 male and 3 female mice) received $0.5 \mathrm{ml}$ isotonic saline intragastrically served as controls [11].

\section{4. Morbidity assessment}

2. 4. 1. In the acute stage (one week after infection)

1- Mice were weighed and observed for clinical signs of infection which scored following the system de- vised by Bartly et al., 2006 [28] as follows:

Score $0=$ Smooth and glossy fur and active

Score $\mathrm{I}=$ Hunched posture and dull or ruffled fur

Score II= Reluctant to move

2- Mice showing clinical signs of infection were examined for tachyzoites in their peritoneal aspirate using Giemsa-stained smear.

2. 4. 2. In the chronic stage (starting from the 6th week post infection to the end of the observation period by the $10^{\text {th }}$ week)

2. 4. 2.1 Estimation of brain cyst burden

Mice were anaesthazied by intraperitoneal injection of pentobarbital sodium (40 mg/kg) and decapitated. Trunk blood collected, serum separated and stored at $-20^{\circ} \mathrm{C}$ for serology. One half of the brain of each mice left for histology the other half homogenized in $1 \mathrm{ml}$ phosphate buffered saline $\mathrm{pH} 7.2$ and the brain cyst burden was estimated by counting the number of cysts in $10 \mu \mathrm{l}$ homogenate [11].

Brain cyst burden $=$ Number of MANSOURA MEDICAL JOURNAL 
cysts in $10 \mu$ l homogenate $X 100 \times$ 2.

\section{4. 2. 2. Scoring of lesions}

One half of the brain of each mice fixed in $10 \%$ formalin. The tissue processed routinely. Paraffin sections cut at $5.0 \mu \mathrm{m}$ thickness and stained with haematoxylin and eosin. The inflammatory reaction and cysts were detected under x400 magnification. The following scoring system was used for grading the brain lesions [29]

$$
\begin{aligned}
& \text { Score } 0 \text { = No lesion } \\
& \text { Score I = Single minimal le- } \\
& \text { sion } \\
& \text { Score II = Widespread minimal } \\
& \text { lesion } \\
& \text { Score III = Single moderate le- } \\
& \text { sion } \\
& \text { Score IV = Widespread moder- } \\
& \text { ate or severe lesion }
\end{aligned}
$$

2. 4. 2. 3. Monitoring serum anti-

\section{Toxoplasma IL 12}

Commercial IL 12 ELISA kit (MyBioSource, Inc., USA) was used following the manufacture instructions.

\subsection{Statistical analysis}

Data were fed to the computer and analyzed using IBM SPSS softVol. 44, No. 1 \& 2 Jan. \& April, 2015 ware package version 20.0. Qualitative data were described using number and percent. Quantitative data were described median, minimummaximum. The results were considered significant when the probability of error is less than $5 \%(p<0.05)$.

\section{RESULTS}

Table (2) shows Toxoplasma tachyzoites were not detected in all 5 infected males showing clinical signs $(0 \%)$ and detected in only one female from all 3 infected females showing clinical signs (33.3\%).

In each mouse, Toxoplasma cysts were counted in one milliliter of brain suspension, as shown in table (3) the mean cyst burden in Toxoplasma-infected female was significantly higher than in Toxoplasmainfected male $(P>0.001)$.

As shown in table (4) the histopathological lesion in Toxoplasmainfected female was significantly higher than in Toxoplasma infected male $(P>0.001)$. There were many inflammatory foci associated with the presence of cysts seen in the brains of infected female mice in which the brain lesions were mostly of score III $(45 \%)$ and score IV(40\%) (Fig. 1). 
Mamdouh Hegazya et al ....

On the other hand, there were mild

As shown in table (5) the serum inflammatory foci and few number of anti-Toxoplasma IL-12 in Toxoplascysts seen in the brains of infected male mice in which the brain lesions were mostly of score I (45\%) (Fig. 2). ma- infected male was significantly higher than in Toxoplasma-infected female $(P>0.001)$.

Table (1): shows the clinical signs of acute illness in 20 male and 20 female mice infected with Toxoplasma gondii from $1^{\text {st }}$ up to $6^{\text {th }}$ week post infection

\begin{tabular}{|c|c|c|c|c|}
\hline & \multicolumn{2}{|c|}{$\begin{array}{l}\text { Infected male mice } \\
(\mathrm{n}=20)\end{array}$} & \multicolumn{2}{|c|}{$\begin{array}{l}\text { Infected female mice } \\
(\mathrm{n}=20)\end{array}$} \\
\hline & No. & $\%$ & No. & $\%$ \\
\hline \multicolumn{5}{|l|}{$1^{\text {st }}$ week: } \\
\hline Score 0 & 20 & 100.0 & 20 & 100.0 \\
\hline Score I & 0 & 0.0 & 0 & 0.0 \\
\hline Score II & 0 & 0.0 & 0 & 0.0 \\
\hline \multicolumn{5}{|l|}{$2^{\text {nd }}$ week: } \\
\hline Score 0 & 19 & 95.0 & 20 & 100.0 \\
\hline Score I & 1 & 5.0 & 0 & 0.0 \\
\hline Score II & 0 & 0.0 & 0 & 0.0 \\
\hline \multicolumn{5}{|l|}{$3^{\text {rd }}$ week: } \\
\hline Score 0 & 18 & 90.0 & 19 & 95.0 \\
\hline Score I & 2 & 10.0 & 1 & 5.0 \\
\hline Score II & 0 & 0.0 & 0 & 0.0 \\
\hline \multicolumn{5}{|l|}{$4^{\text {th }}$ week: } \\
\hline Score 0 & 18 & 90.0 & 18 & 90.0 \\
\hline Score I & 2 & 10.0 & 2 & 10.0 \\
\hline Score II & 0 & 0.0 & 0 & 0.0 \\
\hline \multicolumn{5}{|l|}{$5^{\text {th }}$ week: } \\
\hline Score 0 & 16 & 80.0 & 17 & 85.0 \\
\hline Score I & 3 & 15.0 & 2 & 10.0 \\
\hline Score II & 1 & 5.0 & 1 & 5.0 \\
\hline \multicolumn{5}{|l|}{$6^{\text {th }}$ week: } \\
\hline Score 0 & 15 & 75.0 & 17 & 85.0 \\
\hline Score I & 3 & 15.0 & 2 & 10.0 \\
\hline Score II & 2 & 10.0 & 1 & 5.0 \\
\hline
\end{tabular}

Fisher's and Monte-carlo exact test between male and female infected mice was not statistically significant $(\mathrm{p}>0.05)$. 
Table (2): Tachyzoites in peritoneal aspirate of Toxoplasma-symptomatic mice

\begin{tabular}{|l|l|l|l|l|}
\hline \multirow{2}{*}{$\begin{array}{l}\text { Toxoplasma } \\
\text { tachyzoite }\end{array}$} & \multicolumn{2}{|l|}{$\begin{array}{l}\text { lymptomatic male mice } \\
(\mathrm{n}=5)\end{array}$} & \multicolumn{3}{l|}{$\begin{array}{l}\text { Symptomatic female mice } \\
(\mathrm{n}=3)\end{array}$} \\
\cline { 2 - 5 } & No. & $\%$ & No. & $\%$ \\
\hline Yes & 0 & 0.0 & 1 & 33.3 \\
\hline No & 5 & 100.0 & 2 & 66.7 \\
\hline
\end{tabular}

Fisher's exact test between male and female infected mice was not statistically significant $(\mathrm{p}>0.05)$.

Table (3): Brain cyst burden in Toxoplasma-infected male and female mice

\begin{tabular}{|l|l|l|l|}
\hline \multicolumn{1}{|c|}{ Mice } & \multicolumn{2}{|l|}{ Toxoplasma brain cyst no. } & \multirow{2}{*}{ P value } \\
\cline { 2 - 3 } & Range & Mean \pm SD & \\
\hline Male (n=20) & $1000-2400$ & $1790 \pm 407.7$ & $<0.001$ \\
\hline Female (n=20) & & & \\
& $2000-3600$ & $2620 \pm 467.5$ & \\
\hline
\end{tabular}

Student's t-test between male and female infected mice was statistically significant $(\mathrm{P}<0.001)$.

Vol. 44, No. 1 \& 2 Jan. \& April, 2015 
Table (4): Scoring of histopathological lesion in Toxoplasma-infected male and female mice

\begin{tabular}{|c|l|l|l|l|}
\hline Pathological reaction scoring & \multicolumn{2}{|l|}{$\begin{array}{l}\text { Infected male mice } \\
(\mathbf{n = 2 0})\end{array}$} & \multicolumn{2}{l|}{$\begin{array}{l}\text { Infected female mice } \\
(\mathbf{n = 2 0})\end{array}$} \\
\cline { 2 - 5 } & No. & $\%$ & No. & $\%$ \\
\hline $\begin{array}{c}\text { O } \\
\text { (No lesion) }\end{array}$ & 3 & 15.0 & 0 & 0.0 \\
\hline $\begin{array}{c}\text { I } \\
\text { (Single minimal lesion) }\end{array}$ & 9 & 45.0 & 1 & 5.0 \\
\hline $\begin{array}{l}\text { II minimal } \\
\text { (Widespread }\end{array}$ & 3 & 15.0 & 2 & 10.0 \\
\hline $\begin{array}{c}\text { III } \\
\text { (Single moderate lesion) }\end{array}$ & 3 & 15.0 & 9 & 45.0 \\
\hline $\begin{array}{l}\text { IV spread moderate or } \\
\text { (Wide } \\
\text { severe lesion) }\end{array}$ & & & & \\
\hline
\end{tabular}

Monte-carlo exact test (were done for cells with numbers' $<5$ ) between male and female infected mice was statistically significant $(p<0.001)$.

Table (5): Serum anti-Toxoplasma IL-12 monitoring in mice surviving in observation period of 10 weeks

\begin{tabular}{|l|l|l|l|}
\hline \multirow{2}{*}{ Mice } & \multicolumn{2}{|l|}{ Anti-Toxoplasma IL-12 } & \multirow{2}{*}{ P value } \\
\cline { 2 - 3 } & Median & Range & \\
\hline Male (n=20) & 62.5 & $26.23-95.02$ & $<0.001$ \\
& & & \\
\hline Female (n=20) & 28.6 & $25.40-74.16$ & \\
\hline
\end{tabular}

Mann Whitney test between male and female infected mice was statistically significant $(\mathrm{p}<0.001)$. 


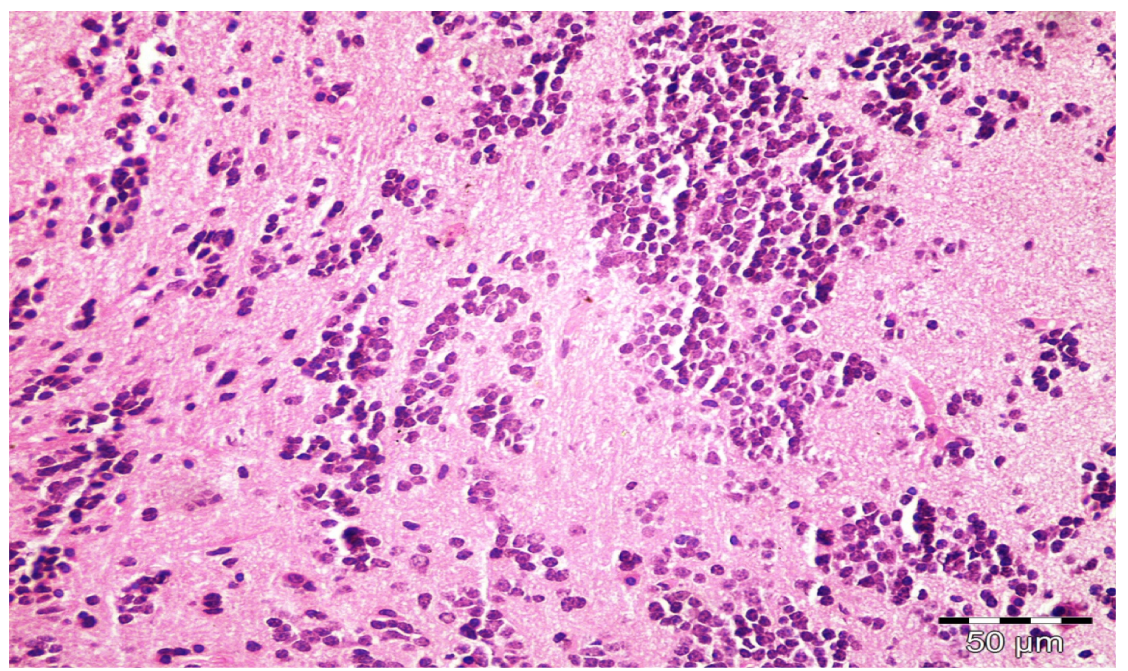

FIG. 1. Brain tissue showing severe inflammatory reaction with lymphocytic infiltration in Toxoplasma-infected female mice (x400) stained with Haematoxylin \& Eosin.

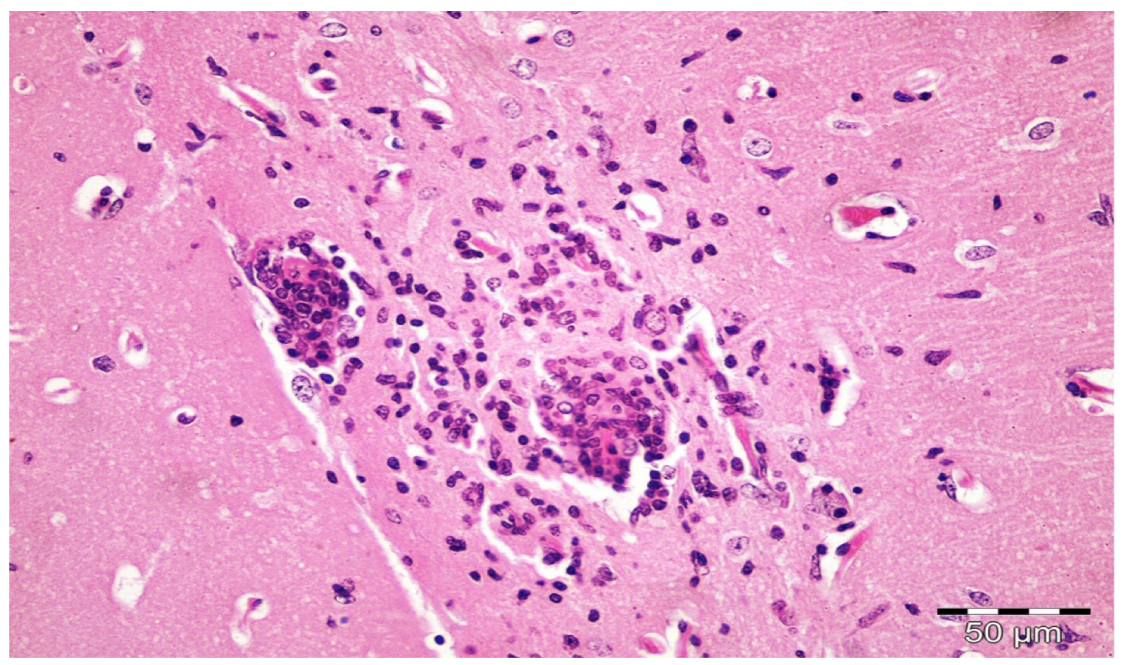

FIG. 2. Brain tissue showing minimal inflammatory reaction with lymphocytic infiltration in Toxoplasma-infected male mice (x400) stained with Haematoxylin \& Eosin.

Vol. 44, No. 1 \& 2 Jan. \& April, 2015 


\section{Mamdouh Hegaz \\ DISCUSSION}

Our results showed that the clinical signs of acute illness in 20 male and 20 female mice infected with the cystogenic ME49 Toxoplasma type II strain from 1st up to 6th week post infection were statistically insignificant $(p>0.05)$. There was no statistical significant difference between males and females, regarding Toxoplasma tachyzoites in the peritoneal aspirate of mice showing clinical signs of toxoplasmosis (From 8 mice showing clinical signs, tachyzoites were detected in only one female from $3(33.3 \%)$ and not detected in any of 5 males).

Our findings are in agreement with Bargan and Sibley (2002) [30] who proved that type I $(\mathrm{RH})$ lineage exhibited a superior migratory capacity in tissues than type II (ME49). Type I lineage has been shown to contain those strains of Toxoplasma gondii that are acutely virulent in laboratory mice [31]. On the other hand in laboratory mice model type II lineages produce high cyst burden, and are prone to reactivate in experimentally immune suppressed mice [ ${ }^{32}$, 33].

Also, Dubremetz and Lebrun [34] reported that the differences in susceptibility to infection with Toxoplasma gondii and the features of acute disease in different hosts have been attributed to the parasite stage (tachyzoite or bradyzoite), inoculation route, host genetic background, and parasite strain.

Also, our findings are in agreement with data showed that infected males and females died during the acute phase, between 9 and 13 days post-infection with the presence of tachyzoites in peritoneal fluids, weight loss and several clinical signs were observed when infected with highly virulent strains. While in mice, the acute phase of infection with proliferating tachyzoites lasts approximately 14 to 21 days when infected with intermediate or avirulent strains. The tachyzoites proliferation is controlled by the host immune response, and a small subpopulation that converts to bradyzoites, forming tissue cysts in the musculature and central nervous system, which results in a lifelong chronic infection [35].

Our results showed that females are more susceptible to Toxoplasma infection than males as there were significant statistical difference be-

MANSOURA MEDICAL JOURNAL 
tween both sex regarding mean cyst burden and the histopathological lesion $(P>0.001)$.

The results are in accordance with the hypothesis that during latent toxoplasmosis, significant modifications of cytokine production and modulation of some parameters of the immune response occurred. The most remarkable were the changes in the in vitro production and in the in vivo serum levels of IL-12 might be just a non-adaptive side effect of Toxoplasma-induced immunosuppression [36].

Also, Henry and Beverley [23] were the first to demonstrate differences in the immune and inflammatory responses of male and female mice following infection with Toxoplasma gondii. In those studies, female mice developed more severe brain inflammation than male mice following infection.

These differences in susceptibility correlate with functional differences in the immune response, with male mice producing IL-12 and IFN- $\gamma$ earlier and in greater quantities than female mice [25]. Alteration of the sex hormonal milieu in both male and female induces changes in both the severity and character of the lesions caused by toxoplasmic infection, estrogen has been shown to affect IL-12 and IFN- $\gamma$ production through an estrogen response element present on the gene's promoter [37]. In addition, the generally inhibitory effects of estrogen and progesterone on macrophage function and nitric oxide production also contribute to the comparative susceptibility of female mice to Toxoplasma gondii infection [38].

Also, our findings are similar to those reported by others in rats [39], and mice [40], and suggest a depressive effect of Hexoestrol upon cellular immunity. This has also been confirmed by a depression of the reaction of delayed hypersensitivity seen after oestrogen administration [41].

Our observations, along with those of Lindberg and Frenkel (1977) [42] in mice, suggest that while active cellular immunity is important in resistance to toxoplasmic infection, the role of circulating antibody is uncertain. The present findings support the possibility that cellu- 
lar immunity plays a major role in the pathogenesis of the lesions. However, strong suppression of cellular immunity may lead to an overwhelming toxoplasmosis and death.

On the other hand, Flegr et al (2008) [43] reported that Toxoplasma-infected men have a higher concentration of testosterone, while Toxoplasma-infected women have a lower concentration of testosterone than the normal controls. Also, treatment of Toxoplasma-infected female mice with testosterone reduce intestinal parasite numbers and pathology [44].

\section{Conclusion}

In conclusion, this study demonstrates no sex differences regarding clinical signs in acute stage in mice infected by cystogenic strain. While, there is significant difference regarding inflammatory reaction and cyst burden which is more marked in females than males. Significant difference in the anti-Toxoplasma IL-12 between males and females explain low susceptibility to Toxoplasma infection in males in comparison to females.

\section{REFERENCES}

1. Boughattas, S.; Ayari, K.; Aoun,
K.; Bouratbine, A. (2014): Survey of the parasite Toxoplasma gondii in human consumed ovine meat in Tunis city. PloS One 2014.; 9(1): e85044.

2. Ceni-Goga, B. T.; Rossitto, P. C.; Sechi, P.; Mecrindle, C. M.; Cullor, J. S. (2011) : Toxoplasma in animals, food, and humans: an old parasite of new concern. Foodborne Pathog. Dis.; 8: 751-762.

3. Simanjuntak, T. P.; Hatta, M.; Sirait, R. H. et al . (2017) : Analysis Concentration of Toxoplasma gondii on AntiToxoplasma IgG-IgM Antibody Levels, and the Outcomes of Pregnancy in Mice Balb/c. Open Journal of Obstetrics and Gynecology.; 7: 281-289.

4. Dukaczewska, A.; Tedesco, R.; Liesenfeld, O. (2015) : Experimental models of ocular infection with Toxoplasma gondii. Eur. J. Microbiol. Immunol.; 4(5): 293-305.

MANSOURA MEDICAL JOURNAL 
5. Wang, Z. D.; Liu, H. H.; Ma, Z. X.; Ma, H. Y.; Li, Z. Y.; Yang, Z. B.; Zhu, X. Q.; Xu, B.; Wei, F.; Liu, Q. (2017): Toxoplasma gondii Infection in Immunocompromised Patients: A Systematic Review and MetaAnalysis. Front. Microbiol.; 8: 389.

6. Murata, Y.; Sugi, T.; Weiss, L. M.; Kato, K. (2017) : Identification of compounds that suppress Toxoplasma gondii tachyzoites and bradyzoites. PLoS ONE.; 12(6): e0178203.

7. Pomares, C.; Zhang, B.; Arulkumar, S.; Gonfrier, G.; Marty, P.; Zhao, S. et al. (2017) : Validation of IgG, IgM multiplex plasmonic gold platform in French clinical cohorts for the serodiagnosis and follow-up of Toxoplasma gondii infection. Diagnostic Microbiology and Infectious Disease.; 87: 213-218.

8. Dubey, J. P.; Verma, S. K.; Villena, I.; Aubert, D.; Geers,
R.; Su, C.; Lee, E.; Forde, M.; Krecek, R. (2016) : Toxoplasmosis in the Caribbean islands: literature review, seroprevalence in pregnant women in ten countries, isolation of viable Toxoplasma gondii from dogs from St. Kitts, West Indies with report of new $T$. gondii genetic types. Parasitol Res.; 115: 1627-1634.

9. Prusa, A. R.; Kasper, D. C.; Pollak, A.; Gleiss, A.; Waldhoer, T.; Hayde, M. (2015) : The Austrian toxoplasmosis. Clin Infect Dis.; 60: e410.

10. Ding, H.; Gao, Y.; Deng, Y.; Lu, D. et al. (2017) : A systemic review and metaanalysis of the seroprevalence of Toxoplasma gondii in cats in mainland China. Parasites \& Vectors.; 10: 27.

11. Kanková, S.; Holá,, V.; Zajícová, A.; Kodym, P.; Flegr, J. (2010) : Modulation of immunity in mice 
Mamdouh Hegazya et al ....

with latent toxoplasmosis-

the experimental support for the immunosuppression hypothesis of Toxoplasmainduced changes in reproduction of mice and humans case report. Parasitol. Res.; 107: 1421-1427.

12. Filisetti, D.; Candolfi E. (2004) : Immune response to Toxoplasma gondii. Ann. Ist. Super. Sanita.; 40: 71-80.

13. El-Henawy, A. A.; AbdelRazik, A.; Zakaria, S.; Elhammady, D.; Saudy, N.; Azab, M. S. (2015) : Is toxoplasmosis a potential risk factor for liver cirrhosis?. Asian Pacific Journal of Tropical Medicine.; 8(10): 784-791.

14. Fernández, C.; Jaimes, J.; Ortiz, M. C.; Ramírez, J. D. (2016) : Host and Toxoplasma gondii genetic and non-genetic factors influencing the development of ocular toxoplasmosis: A systematic review Infection. Genetics and Evolution.; 44: 199-209.
15. Wildling, E.; Winkler, S.; Kremsner, P. G.; Brandts, C.; Jenne, L.; Wernsdorfer, W. H. (1995) : Malaria epidemiology in the province of MoyenOgoov, Gabon. Trop. Med. Parasitol.; 46: 77-82.

16. Jones, T. C.; Johnson, W. D. Jr.; Barretto, A. C.; Lago, E.; Badaro, R.; Cerf, B.; Reed, S. G.; Netto, E. M.; Tada, M. S.; Franca, T. F. (1987) : Epidemiology of American cutaneous leishmaniasis due to Leishmania braziliensis braziliensis. J. Infect. Dis.; 156: 73-83.

17. Klein, S. L. (2000) : The effects of hormones on sex differences in infection: from genes to behavior. Neurosci. Biobehav. Rev.; 24: 627-638.

18. Whitacre, C. C.; Reingold, S. C.; O'Looney, P. A. (1999) : A gender gap in autoimmunity. Science.; 283 : 1277-1278.

19. Rajan, T.V.; Nelson, F. K.; MANSOURA MEDICAL JOURNAL 
90

\section{Shultz, L.D.; Beamer, W.}

G.; Yates, J.; Greiner, D.

L. (1994) : Influence of gonadal steroids on susceptibility to Brugia malayi in scid mice. Acta. Trop.; 56: 307-314.

20. Gerard, C. C.; Bruyns, A.; Marchant, D.; Abramowicz, P.; Vandenabeele, A. (1990) : The influence of beta-estradiol and progesterone on interferon gamma production in vitro. Int. J. Neurosci.; 51:315-317.

21. Wunderlich, F.; Marinovski, P.; Benten, W. P.; Schmitt-Wrede, H. P.; Mossmann, H. (1991) : Testosterone and other gonadal factor(s) restrict the efficacy of genes controlling resistance to Plasmodium chabaudi malaria. Parasite Immunol.; 13: 357-367.

22. Machala, L.; Kodym, P.; Maly, M.; Geleneky, M.; Beran, O.; Jilich, D. (2015) : Toxoplasmosis in immunocompromised patients. Epidem- iol. Mikrobiol. Imunol.; 64: 59-65.

23. Henry, L.; Beverley, J. K. A. (1976) : Age and sex differences in the response of lymph node post-capillary venules in mice infected with Toxoplasma gondii. J. Exp. Pathol.; 57: 274-281.

24. Pung, O. J.; Luster, M. I. (1986) : Toxoplasma gondii: decreased resistance to infection in mice due to estrogen. Exp.Parasitol.; 61: 4856.

25. Walker, W.; Roberts, C. W.; Ferguson, D. J.; Jebbari, H.; Alexander, J. (1997) : Innate immunity to Toxoplasma gondii is influenced by gender and is associated with differences in interleukin-12 and gamma interferon production. Infect. Immun.; 65: 1119-1121.

26. Roberts, C. W.; Cruickshank, S. M.; Alexander, J. (1995) : Sex-determined resistance to Toxoplasma gondii is associated with 
Mamdouh Hegazya et al ....

91

temporal differences in cytokine production. Infect. Immun.; 63: 2549-2555.

27. Djurkovic-Djakovic, O.; Milenkovic, V.; Nikolic, A.; Bobic, B.; Grujic, J. (2002) : Efficacy of atovaquone combined with clindamycin against murine infection with a cystogenic (ME49) strain of Toxoplasma gondii. J. Antimicrob.Chemother.; 50: 981987.

28. Bartley, P. M.; Wright, S.; Sales, J.; Chianini, F.; Buxton, D.; Innes, E. A. (2006) : Long-term passage of tachyzoites in tissue culture can attenuate virulence of Neospora caninum in vivo. Parasitol.; 135: 421-432.

29. Shubar, H.; Lachenmaier, S.; Heimesaat, M.; Lohman, U.; Mauludin, R.; Mueller, R.; Fitzner, R.; Borner, K.; Liesenfeld1, O. (2011) : SDS-coated atovaquone nanosuspensions show improved therapeutic efficacy against experimental acquired and reactivated toxoplasmosis by improving passage of gastrointestinal and blood-brain barriers. J. Drug. Target.; 19(2): 114124.

30. Barragan, A.; Sibley, L. D. (2002) : Transepithelial migration of Toxoplasma gondii is linked to parasite motility and virulence. J. Exp. Med.; 195: 1625-1633.

31. Su, C.; Howe, D. K.; Dubey, J. P.; Ajioka, J. W.; Sibley, L. D. (2002) : Identification of quantitative trait loci controlling acute virulence in Toxoplasma gondii. Proc. Natl. Acad. Sci.; 99: 1075310758.

32. Suzuki, Y.; Joh, K.; Orellana, M. A.; Conley, F. K.; Remington, J. S. (1991) : Agene(s) within the $\mathrm{H}-2 \mathrm{D}$ region determines the development of toxoplasmic encephalitis in mice. Immunology.; 74: 732-739.

33. Suzuki, Y.; Joh, K. (1994) : EfMANSOURA MEDICAL JOURNAL 
92

\section{SEX-RELATED EFFECTS ON
fect of the strain of Toxo-} plasma gondii on the development of toxoplasmic encephalitis in mice treated with antibody to interferongamma. Parasitol Res.; 80: 125-30.

34. Dubremetz, J. F.; Lebrun, M. (2012) : Virulence factors of Toxoplasma gondii. Microbes Infect.; 14(15): 1403-1410.

35. Munoz, M.; Liesenfeld, O.; Heimesaat, M. M. (2011) : Immunology of Toxoplasma gondii. Immunol Rev.; 240(1): 269-285.

36. Kanková, S.; Kodym, P.; Frynta, D.; Vavrinová, R.; Kubena, A.; Flegr, J. (2007) : Influence of latent toxoplasmosis on the secondary sex ratio in mice. Parasitol.; 134: 17091717.

37. Fox, H. S.; Bond, B. L.; Parslow, T. G. (1991) : Estrogen regulates the IFNgamma promoter. J. Immunol.; 146: 4362-4367.

Vol. 44, No. 1 \& 2 Jan. \& April, 2015
38. Miller, L.; Hunt, J. S. (1998): Regulation of TNF-alpha production in activated mouse macrophages by progesterone. J. Immunol.; 160: 5098-5104.

39. Heim, L.M.; Timiras, P. S. (1963) : Gonad-Brain relationship: precocious brain maturation after estradiol in rats. Endocrinology.; 72: 598.

40. Kalland, T.; Fossberg, T. M.; Forsberg, J. G. (1978) : Effect of estrogen and corticosterone on the lymphoid system in neonatal mice. Exp. Molec. Path.; 28: 76 .

41. Ablin, R. J.; Bruns, G. R.; Guinan, P. et al. (1974): Immunosuppressive effect of estrogen on thymic dependent lymphocytic blastogenesis. Urol. Res. 2: 69.

42. Lindberg, R. E.; Frenkel, J. K. (1977) : Toxoplasmosis in nude mice. A. Parasitol.; 63: 219. 
Mamdouh Hegazya et al ....

93

43. Flegr, J.; Lindova, J.; Ko- 44. Kanková, S.; Kodym, P.; Flegr, dym, P. (2008): Sex-depe-

J. (2011): Direct evidence ndent toxoplasmosis-

of Toxoplasma-induced

associated differences in

changes in serum testoste-

testosterone concentration

rone in mice.

in humans. Parasitol.; 135:

427-431.

Exp.Parasitol.; 128: 181-

183.

MANSOURA MEDICAL JOURNAL 